\title{
Assessment of Annual Wind Energy Potential at Three Sites in Iraq for Wind Energy Applications
}

\author{
Ali M. Rasham \\ University of Baghdad \\ College of Engineering \\ Energy Engineering \\ Department
}

\begin{abstract}
Assessment of annual wind energy potential for three selected sites in Iraq has been analyzed in the present work. The wind velocities data from August 2014 to July 2015 were collected from the website of Weather Underground Organization (WUO) at stations elevation $(35 \mathrm{~m}, 32 \mathrm{~m}$, and $17 \mathrm{~m})$ for Baghdad, Najaf, and Kut Al-Hai respectively. Extrapolation of stations elevation and wind velocities was used to estimate wind velocities at $(60 \mathrm{~m}, 90 \mathrm{~m}$, and $120 \mathrm{~m})$. The objectives are to analyze the wind speed data and assess the wind energy potential for wind energy applications. Computer code for MATLAB software has been developed to solve the mathematical model. The results are presented as a monthly and annual average for wind velocities, standard deviation, shape factor, scale factor, probability density function, cumulative distribution function, measured and Weibull estimated of wind power density, wind energy density, determination factor, and root mean square error. A comparison is made with the previous studies to select wind class of selected sites in the present work. At selected stations, the wind energy potential was the best for Najaf, Kut Al-Hai, and Baghdad respectively. According to the international wind classification, the selected sites has fair class at stations elevation. Kut Al-Hai has fairly good class at selected heights. While Najaf have fairly good at $(90 \mathrm{~m}$, and $120 \mathrm{~m})$ whereas Baghdad has a fairly good class just at $(120 \mathrm{~m})$.
\end{abstract}

\section{Keywords}

Wind energy potential, wind resource assessment, Weibull parameters.

\section{INTRODUCTION}

In recent years, the successive depletion of conventional resources and an increase in energy demand due to the growth of world's population led to look for about an alternative energy resources. It is worth mentioning that the Renewable Energy is an alternative and successful solution because it is environmentally friendly, abundant, clean, and inexhaustible source. By contrast, the diurnal, seasonal, and yearly fluctuations in the wind adversely affect since it is stochastic quantity. Obviously, the using of renewable energy resources such as wind energy projects instead of conventional energy resources may lessen consequences of atmospheric pollution, the riskiness of global warming, and reducing the depletion of conventional resources. Nowadays, wind energy projects are occupying an advanced ranking as compared with other renewable energy resources and conventional resources. Indeed, the improvements in the modern technology of wind energy projects and its production cost made its growing with fast rate compared to conventional resources and the rest of renewable energy resources. Efforts for assessing wind energy potential are so important in this field. The wind's statistical models are used to analyze and assess the energy potential available for specific sites. Indeed, electric power generation through renewable energy systems in Iraq contributes to increasing the availability of electricity.

It is worth mentioning that the present study is one of the important steps to assess wind energy potential in the selected sites in Iraq. Several studies were presented in this field.

The wind energy potential assessment for five coastal locations of the Kingdom of Saudia Arabia was evaluated [1] Hourly mean wind speed and wind direction of 14 years were presented. The best locations for extracting wind power Yanbo, Dhahran, were analyzed and other three locations were found to have more or less the same results.

The wind characteristics for the Waterloo region in Canada based on a data source measured at an elevation $10 \mathrm{~m}$ above the ground level over a 5-years period (1999-2003) was examined [2]. Characteristics such as diurnal, monthly, seasonal, annual, wind speed variations, and wind direction variations are tested.

The wind energy potential via a software tool at four locations in Ethiopia was investigated and analyzed [3]. The results were given in terms of the monthly average wind speed, probability density function, cumulative density function, and duration curve for all four selected sites. Three of four locations are reasonable for wind energy potential.

In Naxos Island, Greece the Wind energy potential assessment using a real wind data by a measurement mast was presented [4]. Weibull and Rayleigh distribution functions were used to analyze wind characteristics. The selected site falls under class 7 of the International system of wind classification.

For the Sultanate of Oman, the diurnal and seasonal of wind data analysis at different heights covered was analyzed [5]. For average wind speed and direction, the contour maps, tabulated data, and figures were presented. As well as, wind availability and power density were presented as a result of 10 years. The analysis provided a reference for the spatial distribution of wind characteristics for the whole of Oman.

In three locations in the southeastern part of Nigeria, the wind speed characteristics and wind energy potential using wind speed data measured at a height of $10 \mathrm{~m}$ between 25 and 37 years were investigated [6]. At a height of $10 \mathrm{~m}$, the annual mean of wind speed, power densities, most probable wind speed, the wind speed carrying maximum energy was determined. The annual energy output and capacity factor for 
selected turbines, as well as the water produced by the windmill, were determined.

In Kurdistan province, Iran, the wind energy potential at different heights with six methods for five stations was assessed [7]. The annual shape and scale factors were estimated. According to 100 years return period, the stations rank was as: Zarineh Obato, Bijar, Ghorveh, Saghez, and Sanandaj.

The electricity generation potential from the wind at Kano, Nigeria via monthly wind speed data at a height of $10 \mathrm{~m}$ for 21 years were assessed and analyzed [8]. The monthly average of wind speed, wind power, and wind speed for dry and wet seasons was estimated. Also, the shape factor, scale factor, most frequent wind speed, and wind speed contributing maximum energy were determined. The wind speed at and above the height of $10 \mathrm{~m}$ was economically viable for generating electricity from the wind.

The wind energy potential for Ardabil city of Iran was investigated [9] via collecting the mean wind speed data for six years (2005-2010). The monthly, and annual mean wind speed, monthly mean shape and scale factors, also the higher and lower monthly wind power densities were estimated. The wind potential is very suitable for the off-grid connections and is acceptable for connecting to the power grid.

A similar study was presented for Basrah, Nasiriyah, and Amarah in Iraq by the Author [10] to analyze wind speed and assess annual wind energy potential. Basrah at $(60 \mathrm{~m}, 90 \mathrm{~m}$, and $120 \mathrm{~m})$ and Nasiriyah at $(120 \mathrm{~m})$ are acceptable for connecting to the power grid. In the present study, other three sites were presented in the same field.

\section{SITES INFORMATION and WIND DATA SOURCE}

The wind data for Baghdad, Najaf, and Kut Al-Hai sites in Iraq were collected from the metrological weather website of weather underground Organization (WUO) [11]. The collected wind velocities data were compared with wind velocities data from an intellicast website for verification and the collected data were significantly identical. The elevation, latitude, and longitude of selected stations were $(35 \mathrm{~m}$, $\left.33.26^{\circ}, 44.23^{\circ}\right), \quad\left(32 \mathrm{~m}, \quad 31.99^{\circ}, 44.40^{\circ}\right), \quad(17 \mathrm{~m}$, $32.13^{\circ}, 46.04^{\circ}$ ) for Baghdad, Najaf, and Kut Al-Hai respectively. The maximum, minimum, and average daily of wind velocity are available in (WUO) website. According to daily average wind velocities collected from (WUO), the monthly and annually average wind velocities were estimated at stations elevation. Extrapolation of stations elevations and wind velocities has been used to estimate the wind velocities at $60 \mathrm{~m}, 90 \mathrm{~m}$, and $120 \mathrm{~m}$ via wind shear power law. In the present study, the daily average wind velocity was used as input parameter.

\section{MATHEMATICAL MODEL}

The average of measured wind velocities and Weibull estimated wind velocities are calculated as [12, PP. 64]:

$\overline{\mathrm{V}}=\left\{\left\langle\sum_{\mathrm{i}=1}^{\mathrm{N}} \mathrm{V}_{\mathrm{i}}^{3}\right\rangle / \mathrm{N}\right\}^{1 / 3}$

Here $\left(V_{i}\right)$ is the individual wind velocity $(\mathrm{m} / \mathrm{s})$ and $(\mathrm{N})$ is the number of data.
The standard deviation $(\sigma)$ of individual wind velocities from the average value is evaluated as [12, PP. 64]:

$\sigma=\sqrt{\sum_{i=1}^{\mathrm{N}}\left(\mathrm{V}_{\mathrm{i}}-\overline{\mathrm{V}}\right)^{2} / \mathrm{N}}$

Obviously, the air density is change with height. Consequently, the correction of air density has been employed as [13, PP. 31]:

$\rho=\rho_{\mathrm{o}}-\left[1.194 \times 10^{-4} \times \mathrm{H}\right]$

Here $\left(\rho_{\mathrm{o}}=1.225 \mathrm{~kg} / \mathrm{m}^{3}\right)$ represent the air standard density at $\left(\mathrm{T}=15^{\circ} \mathrm{C}\right)$ and $(\mathrm{P}=1 \mathrm{~atm})$, and $(\mathrm{H})$ is the height of stations elevation and selected heights in the present study.

At stations elevation, the shape factor $\left(\mathrm{K}_{1}\right)$ and scale factor $\left(C_{1}\right)$ of Weibull distribution can be expressed as [12, PP.7576]:

$\mathrm{K}_{1}=(\sigma / \overline{\mathrm{V}})^{-1.090}$

$\mathrm{C}_{1}=\left(\overline{\mathrm{V}} \mathrm{K}_{1}^{2.6674} /\left(0.184+0.816 \mathrm{~K}_{1}^{2.73855}\right)\right)$

Extrapolation of wind velocities with height can be calculated via wind shear law as [14, PP.37]:

$\mathrm{V}_{2}=\mathrm{V}_{1}\left(\mathrm{H}_{2} / \mathrm{H}_{1}\right)^{\alpha}$

Here $\left(V_{1}\right)$ is the wind velocity at stations elevation $\left(\mathrm{H}_{1}\right),\left(\mathrm{V}_{2}\right)$ is the wind velocity at selected heights $\left(\mathrm{H}_{2}\right)$, and $(\alpha)$ is the wind shear exponent.

The wind shear exponent can be formulated as [15, PP.15]:

$\alpha=\left[0.096 \log _{10}\left(\mathrm{Z}_{\mathrm{o}}\right)+0.016\left(\log _{10}\left(\mathrm{Z}_{\mathrm{o}}\right)\right)^{2}+0.24\right]$

Here $Z_{0}$ is ground roughness height which is a function of terrain.

The Weibull parameters variation with height at newly selected heights can be evaluated as [7]:

$\mathrm{K}_{2}=\mathrm{K}_{1}\left[1-0.0881 \ln \left(\mathrm{H}_{2} / \mathrm{H}_{1}\right)\right]^{-1}$
$\mathrm{n}=\left[0.37-0.0881 \ln \left(\mathrm{C}_{1}\right)\right]$
$\mathrm{C}_{2}=\mathrm{C}_{1}\left(\mathrm{H}_{2} / \mathrm{H}_{1}\right)^{\mathrm{n}}$

Here $\left(\mathrm{K}_{2}\right)$ is the corrected shape factor at newly selected height, $\left(\mathrm{C}_{2}\right)$ is the corrected scale factor at newly selected height, and (n) is the exponent of Eq. (10).

The Weibull probability density function $f(V)$ and the cumulative distribution $\mathrm{F}(\mathrm{V})$ can be defined as $[4,6,7,8$ and 12, PP. 68]:

$f(V)=[K / C][V / C]^{K-1} e^{-(V / C)^{K}}$
$F(V)=\int_{0}^{\infty} f(V) d V=1-e^{-(V / C)^{K}}$

Here $(\mathrm{K})$ is the shape factor at stations elevation or at selected heights $(60 \mathrm{~m}, 80 \mathrm{~m}, 100 \mathrm{~m})$, and $(\mathrm{C})$ is the scale factor at stations elevation or at selected heights $(60 \mathrm{~m}, 80 \mathrm{~m}, 100 \mathrm{~m})$. 
According to Weibull distribution, the average wind speed, and standard deviation also at stations elevations or at selected heights can be estimated as [7, 8, and 12, PP. 69-71]:

$\overline{\mathrm{V}}=\mathrm{C} \Gamma[1+(1 / \mathrm{K})]$

$\sigma=\mathrm{C}\left\{\Gamma[1+(2 / \mathrm{K})]-\Gamma^{2}[1+(1 / \mathrm{K})]\right\}^{1 / 2}$

Here $\Gamma$ is the gamma function, which is defined as:

$\Gamma(\mathrm{x})=\int_{0}^{\infty} \mathrm{t}^{(\mathrm{x}-1)} \mathrm{e}^{-\mathrm{t}} \mathrm{dt}$

Here the parameter $(\mathrm{t})$ is equal to $\left((\mathrm{V} / \mathrm{C})^{\mathrm{K}}\right),(\mathrm{V})$ is the wind velocity, and (x) is a positive number.

The individual of measured wind power density $\left(\mathrm{PD}_{\mathrm{mi}}\right)$ and wind energy density $\left(\mathrm{ED}_{\mathrm{mi}}\right)$ at any height can be considered as [9]:

$\mathrm{PD}_{\mathrm{mi}}=(1 / 2) \rho \overline{\mathrm{V}}_{\mathrm{i}}^{3}$

$\mathrm{ED}_{\mathrm{mi}}=\mathrm{PD}_{\mathrm{mi}} \times \mathrm{T}$

Here (T) is the time factor, which is considered to be the hour's number for the monthly and annual durations.

Accordingly, the overall average of measured wind power density $\left(\mathrm{PD}_{\mathrm{mt}}\right)$ and wind energy density $\left(\mathrm{ED}_{\mathrm{mt}}\right)$ can be written as [9]:

$$
\begin{aligned}
& \mathrm{PD}_{\mathrm{mt}}=\left(\left(\sum_{\mathrm{i}=1}^{\mathrm{N}}(1 / 2) \rho \overline{\mathrm{V}}_{\mathrm{i}}^{3}\right) / \mathrm{N}\right) \\
& \mathrm{ED}_{\mathrm{mt}}=\mathrm{PD}_{\mathrm{mt}} \times \mathrm{T}
\end{aligned}
$$

According to the Weibull distribution, the Weibull estimated wind power density $\left(\mathrm{PD}_{\mathrm{EW}}\right)$ and wind energy density $\left(\mathrm{ED}_{\mathrm{EW}}\right)$ at any height, can be expressed as $[6,7]$ :

$$
\begin{aligned}
& \mathrm{PD}_{\mathrm{EW}}=(1 / 2) \rho \mathrm{C}^{3} \Gamma(1+\langle 3 / \mathrm{K}\rangle) \\
& \mathrm{ED}_{\mathrm{EW}}=(1 / 2) \rho \mathrm{C}^{3} \Gamma(1+\langle 3 / \mathrm{K}\rangle) \mathrm{T}
\end{aligned}
$$

The accuracy of Weibull distribution performance in estimating the sites actual parameters with predicted Weibull results can be check by the determination factor $\left(\mathrm{R}^{2}\right)$ and root mean square error (RMSE) as [9]:

$\mathrm{R}^{2}=\left[\frac{\left(\sum_{\mathrm{i}=1}^{\mathrm{N}}\left(\mathrm{y}_{\mathrm{i}}-\mathrm{z}_{\mathrm{i}}\right)^{2}-\sum_{\mathrm{i}=1}^{\mathrm{N}}\left(\mathrm{x}_{\mathrm{i}}-\mathrm{y}_{\mathrm{i}}\right)^{2}\right)}{\left(\sum_{\mathrm{i}=1}^{\mathrm{N}}\left(\mathrm{y}_{\mathrm{i}}-\mathrm{z}_{\mathrm{i}}\right)^{2}\right)}\right]$

$\operatorname{RMSE}=\left[\left(\sum_{\mathrm{i}=1}^{\mathrm{N}}\left(\mathrm{y}_{\mathrm{i}}-\mathrm{x}_{\mathrm{i}}\right)^{2} / \mathrm{N}\right)\right]^{1 / 2}$

Here $\left(y_{i}\right),\left(x_{i}\right)$, and $\left(z_{i}\right)$ is the actual data, predicted Weibull results, and mean of actual data respectively.

\section{RESULTS AND DISCUSSION}

In this study, a daily average of wind speed data for Baghdad, Najaf, and Kut Al-Hai from August 2014 to July 2015 was collected and analyzed. Monthly and annually average of wind velocities, standard deviation, wind power densities, and wind energy densities estimated according to measured wind velocities. Also, according to the Weibull distribution the monthly and annually average of wind velocities, standard deviation, shape factor, scale factor, wind power densities, and wind energy densities were determined.
In general, the monthly and annual average of the measured and Weibull estimated wind velocities for the same site of selected sites are approximately identical. Fig.1 illustrates the monthly and annual average for measured and Weibull estimated of wind velocities for selected sites at station elevations. Obviously, the wind velocity is changed randomly because it is from stochastic quantities. The higher and lower of the monthly average of wind velocities according to measured and Weibull distribution, were in July and December respectively for Baghdad, at July and December respectively for Najaf, and at June and December respectively for Kut-AlHai. In general, Najaf has the highest annual average of wind velocity among the other sites. The monthly and annual average of wind velocities are summarized in Tables (1, 2, and 3).

Fig. 2 displays the wind velocity profiles (boundary layer of the wind above ground surface) for selected sites at station elevations and selected heights based on annual shape factor and scale factors. The change in wind speed with height was estimated by using wind shear power law. Extrapolation of stations elevations used to estimate the wind velocities at $(60 \mathrm{~m}, 90 \mathrm{~m}$, and $120 \mathrm{~m})$ via wind shear power law. The highest wind velocities were for Kut Al-Hai, Najaf, and Baghdad respectively. In fact, the candidate site for wind energy application has annual average wind velocity as minimum as $(5 \mathrm{~m} / \mathrm{s})$ at a hub height of wind turbines [12]. At selected heights, the selected sites had an annual average wind velocity more than $(5 \mathrm{~m} / \mathrm{s})$ except Baghdad site at height of $(60 \mathrm{~m})$. Consequently, the selected sites are a candidate for wind energy applications.

In the present study, the wind energy analysis is achieved by using the Weibull distribution. It is used to describe the wind variations with suitable accuracy. Fig.3 illustrate the probability density function and cumulative distribution function of selected sites at stations elevation in order to characterize the wind velocity variations for the selected sites.

Fig. 4 illustrates the monthly and annual average of wind power density at stations elevation of selected sites. Fig. 5 shows the annual average wind power density at selected heights $(60 \mathrm{~m}, 90 \mathrm{~m}$, and $120 \mathrm{~m})$ for the selected sites. The difference between the Weibull estimated wind power density and measured wind power density showed with the cyan color on the bars of Figs. 4 and 5. The monthly and annual average wind power density at stations elevation are summarized in Tables $(1,2$, and 3). Also, the annual average wind power density at selected heights $(60 \mathrm{~m}, 90 \mathrm{~m}$, and $120 \mathrm{~m})$ are summarized in Table. 4. At station elevations, the higher and lower of the monthly average of wind power densities according to measured and Weibull distribution were at July and December respectively for Baghdad. Whereas the higher and lower of the monthly average of measured wind power densities occurred in July and December respectively for Najaf while it occurred at July and October for Weibull estimated wind power density. Finally, the higher and lower of the monthly average of measured wind power densities for Kut Al-Hai occurred in June and December respectively. The site of the highest annual average wind power density at stations elevation was for Najaf, Kut Al-Hai, and Baghdad respectively. Obviously, at selected heights $(60 \mathrm{~m}, 90 \mathrm{~m}$, and $120 \mathrm{~m}$ ) the site of highest annual average wind power density was for Kut Al-Hai, Najaf, and Baghdad respectively at any of selected heights. As compared with [9], the wind classes of selected sites are summarized in Table. 5 . 
Fig. 6 illustrates the monthly and annual average of wind energy density at stations elevation of selected sites. While Fig. 7 shows the annual average wind energy density at selected heights $(60 \mathrm{~m}, 90 \mathrm{~m}$, and $120 \mathrm{~m})$. The difference between the Weibull estimated wind energy density and measured wind energy density showed with the cyan color on the bars of Figs. 6 and 7. The monthly and annual average wind energy density are summarized in Tables $(\mathbf{1}, \mathbf{2}$, and 3). Also, the annual average wind energy density at selected heights $(60 \mathrm{~m}, 90 \mathrm{~m}$, and $120 \mathrm{~m})$ are summarized in Table. 4. At station elevations, the higher and lower of the monthly average of wind energy densities according to measured and Weibull distribution were at July and December respectively for Baghdad. Whereas the higher and lower of the monthly average of measured wind energy densities occurred in July and December respectively for Najaf while it occurred at July and October for Weibull estimated wind energy density. Finally, the higher and lower of the monthly average of measured wind energy densities for Kut Al-Hai occurred in June and December respectively. Obviously, at selected heights $(60 \mathrm{~m}, 90 \mathrm{~m}, 120 \mathrm{~m})$ the site of highest annual average for measured and Weibull estimated wind energy density was for Kut Al-Hai, Najaf, and Baghdad respectively.

\section{CONCLUSIONS}

Assessment of annual wind energy potential for wind energy applications at Baghdad, Najaf, and Kut Al-Hai was analyzed in this study. The main results and conclusions from this study are as follows:

1. At stations elevation of selected sites, the annual average of measured and Weibull estimated wind velocities was higher for Najaf, Kut Al-Hai, and Baghdad, respectively.
2. At selected heights of selected sites, the annual average of measured and Weibull estimated wind velocities were higher for Kut Al-Hai, Najaf, and Baghdad, respectively.

3. At stations elevation, the estimated annual average of shape and scale factors were $(3.4860,3.0112$, and $2.6851)$ and $(4.3650,4.8509,4.3576 \mathrm{~m} / \mathrm{s})$ for Baghdad, Najaf, and Kut Al-Hai respectively.

4. At stations elevation, the wind classes for selected sites were fair. While the wind classes were fairly good at $(60,90$, and120 m) for Kut Al-Hai site, fairly good at $(90 \mathrm{~m}$, and $120 \mathrm{~m})$ for Najaf site, finally fairly good for Baghdad site just at $(120 \mathrm{~m})$.

5. According to the annual average of wind velocities and wind classes at stations elevation of selected sites, It is worth mentioning that the selected sites are suitable for off-grid applications in remote and populated areas such as pumping water, batteries charging, lightening of streets, and domestic applications.

6. Baghdad site at the selected height of $(120 \mathrm{~m})$, Najaf site at selected heights of $(90 \mathrm{~m}$, and $120 \mathrm{~m})$, and Kut Al-Hai site at selected heights of $(60 \mathrm{~m}$, $90 \mathrm{~m}$, and $120 \mathrm{~m}$ ) are suitable for large-scale wind turbines according to the annual average of wind velocities and wind classes.

7. According to the values of determination factor and root mean square error in the Table. 4, the statistical model of Weibull distribution have a good accuracy in estimating the site's actual data.

8. The present study recommends analyzing the wind energy potential and wind data of other sites for determining suitable sites for wind farms installation.

Table 1. The results of parameters according to measured data and Weibull distribution of Baghdad site at station elevation of ( $35 \mathrm{~m})$.

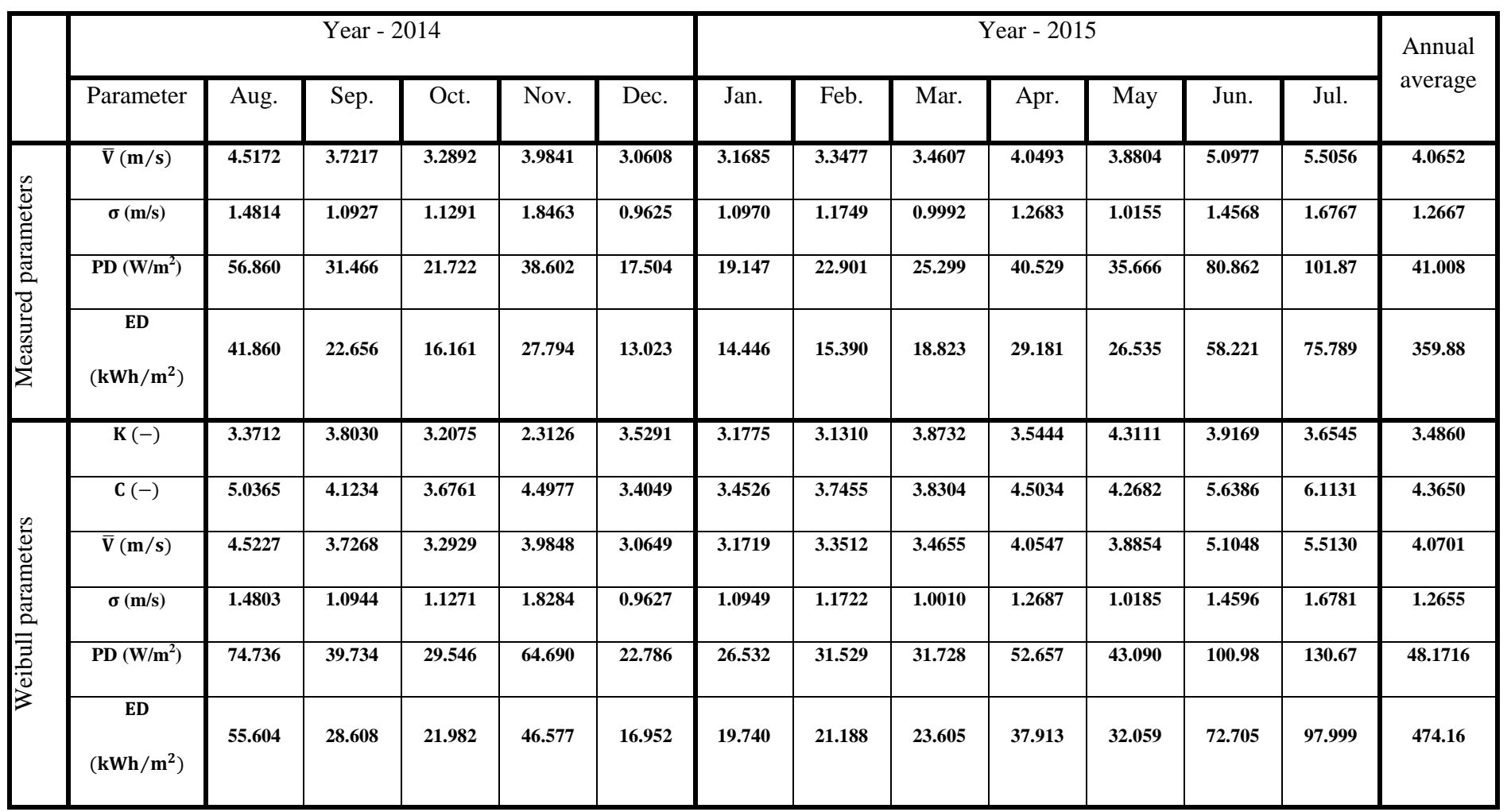


Table 2. The results of parameters according to measured data and Weibull distribution of Najaf site at station elevation of (32m).

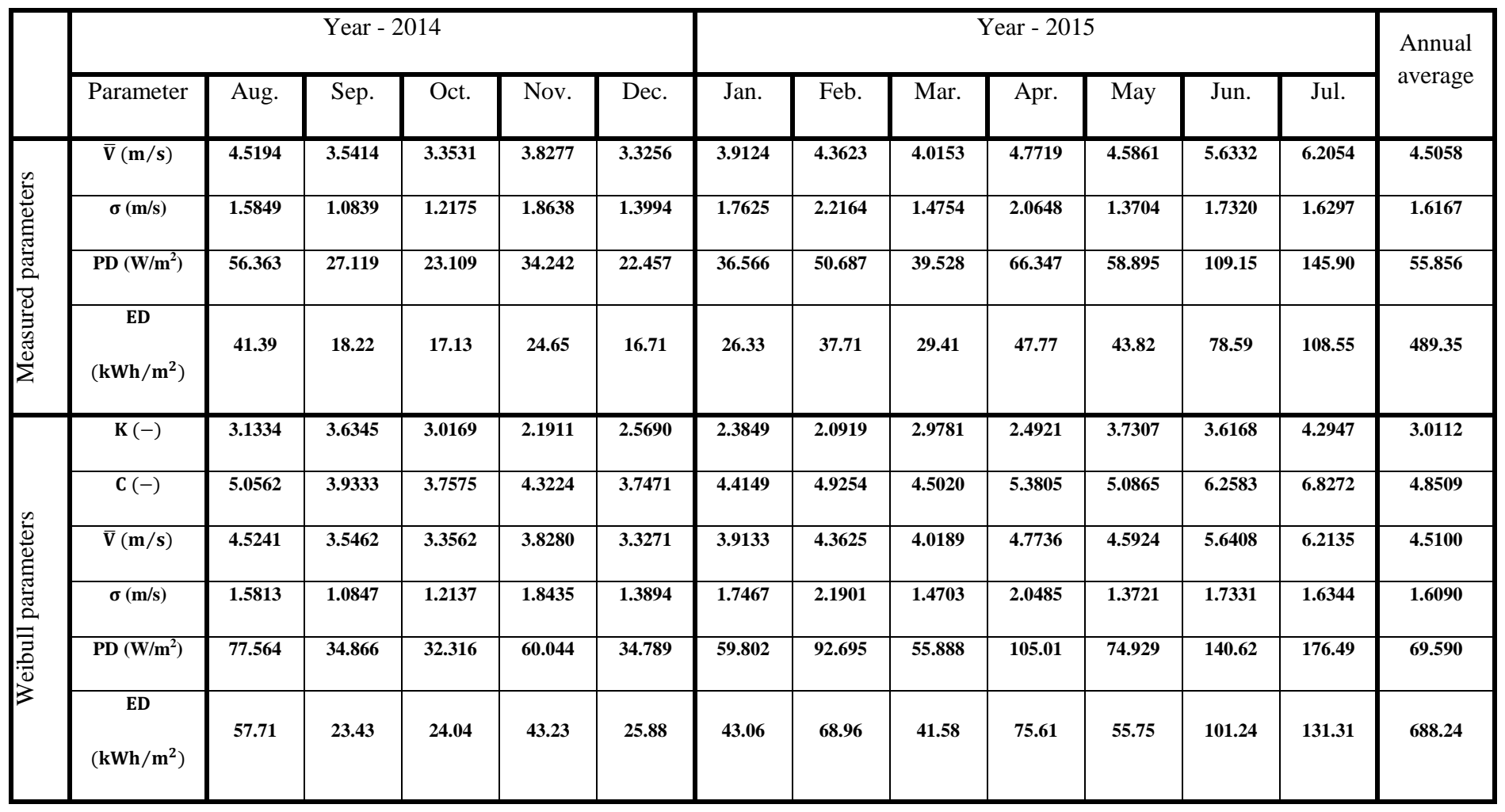

Table 3. The results of parameters according to measured data and Weibull distribution of Kut Al-Hai site at station elevation of $(17 \mathrm{~m})$

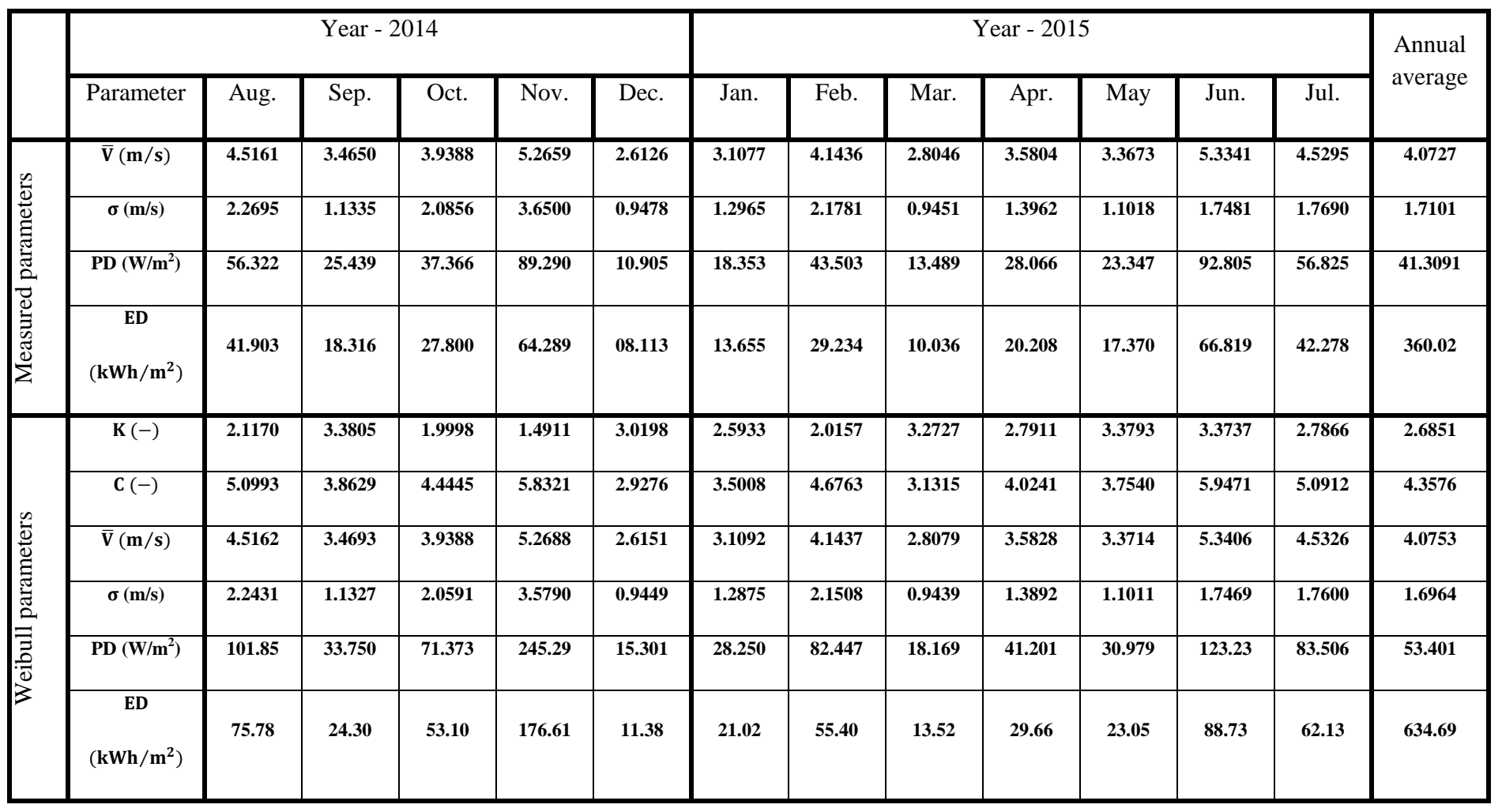


Table 4. The results of annual parameters at selected heights of selected sites in the present study.

\begin{tabular}{|c|c|c|c|c|c|c|c|c|c|c|c|}
\hline \multirow[b]{2}{*}{ Sites } & \multirow[b]{2}{*}{$\begin{array}{l}\text { Height } \\
\text { (m) }\end{array}$} & \multicolumn{3}{|c|}{ Parameters of measured quantities } & \multicolumn{5}{|c|}{ Estimated parameters of Weibull distribution } & \multicolumn{2}{|c|}{ Fit goodness } \\
\hline & & $\begin{array}{c}\overline{\mathbf{V}} \\
(\mathbf{m} / \mathbf{s})\end{array}$ & $\begin{array}{c}\text { PD } \\
\left(\mathbf{W} / \mathbf{m}^{2}\right)\end{array}$ & $\begin{array}{c}\text { ED } \\
\left(\mathbf{k W h} / \mathbf{m}^{2}\right)\end{array}$ & $\mathbf{K}(-)$ & $\mathbf{C}(-)$ & $\begin{array}{c}\overline{\mathbf{V}} \\
(\mathbf{m} / \mathbf{s})\end{array}$ & $\begin{array}{c}\text { PD } \\
\left(\mathbf{W} / \mathbf{m}^{2}\right)\end{array}$ & $\begin{array}{c}\text { ED } \\
\left(\mathbf{k W h} / \mathbf{m}^{2}\right)\end{array}$ & $\mathbf{R}^{2}$ & RMSE \\
\hline \multirow{3}{*}{ 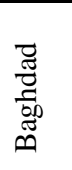 } & 60 & 4.6692 & 61.9851 & 543.96 & 3.6598 & 4.9646 & 4.6252 & 69.7959 & 679.59 & 0.9961 & 0.0962 \\
\hline & 90 & 5.1820 & 84.4837 & 741.41 & 3.8024 & 5.4695 & 5.0937 & 92.2368 & 891.09 & 0.9875 & 0.1984 \\
\hline & 120 & 5.5797 & 105.152 & 922.78 & 3.9105 & 5.8588 & 5.5324 & 112.370 & 1079.8 & 0.9189 & 0.0188 \\
\hline \multirow{3}{*}{. } & 60 & 5.2958 & 90.4407 & 792.34 & 3.1877 & 5.6035 & 5.2007 & 104.623 & 1022.7 & 0.9906 & 0.2516 \\
\hline & 90 & 5.8775 & 123.268 & 1079.9 & 3.3130 & 6.1502 & 5.7035 & 136.105 & 1320.7 & 0.9745 & 0.4622 \\
\hline & 120 & 6.3285 & 153.425 & 1344.1 & 3.4080 & 6.5703 & 6.0905 & 163.991 & 1583.2 & 0.9586 & 0.6336 \\
\hline \multirow{3}{*}{ 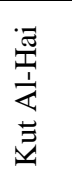 } & 60 & 5.6318 & 108.768 & 947.94 & 3.0207 & 5.8864 & 5.4617 & 123.838 & 1363.1 & 0.9725 & 0.3776 \\
\hline & 90 & 6.2503 & 148.247 & 1292.0 & 3.1471 & 6.4847 & 6.0064 & 162.433 & 1749.2 & 0.9533 & 0.5436 \\
\hline & 120 & 6.7299 & 184.514 & 1608.1 & 3.2435 & 6.9460 & 6.4271 & 196.889 & 2089.3 & 0.9371 & 0.6758 \\
\hline
\end{tabular}

Table 5. Wind classes of selected sites at selected heights according to international wind classification.

\begin{tabular}{|c|c|c|c|c|}
\hline \multirow{2}{*}{ Selected Sites } & \multirow{2}{*}{$\begin{array}{c}\text { Wind classes at station } \\
\text { heights }\end{array}$} & \multicolumn{3}{|c|}{ Wind classes at selected heights } \\
\cline { 3 - 5 } & Fair & $(\mathbf{6 0 m})$ & $\mathbf{( 9 0 m )}$ & Fairly good \\
\hline Baghdad & Fair & Fair & Fairly good & Fairly good \\
\hline Najaf & Fair & Fairly good & Fairly good & Fairly good \\
\hline Kut Al-Hai & & & & \\
\hline
\end{tabular}

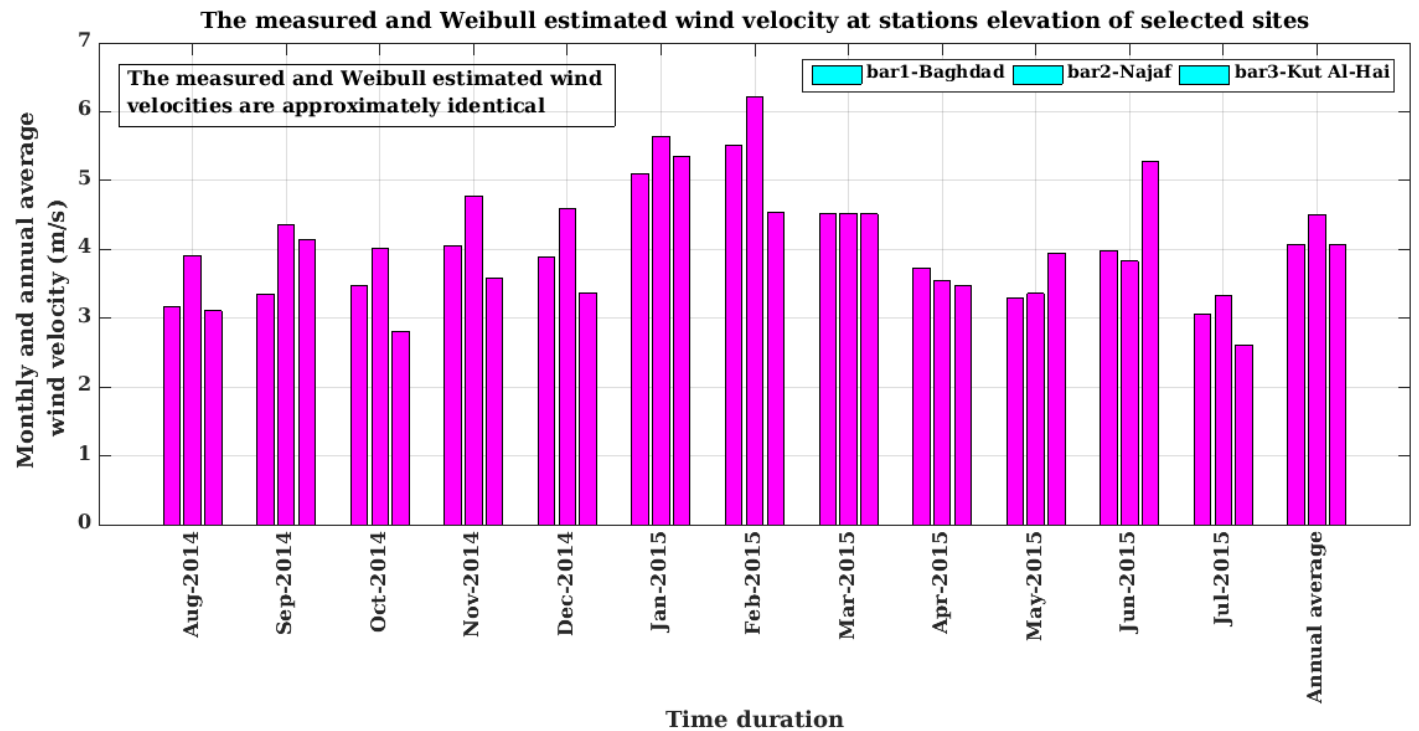

Fig 1: A monthly and annual average of wind velocity at stations elevation. 


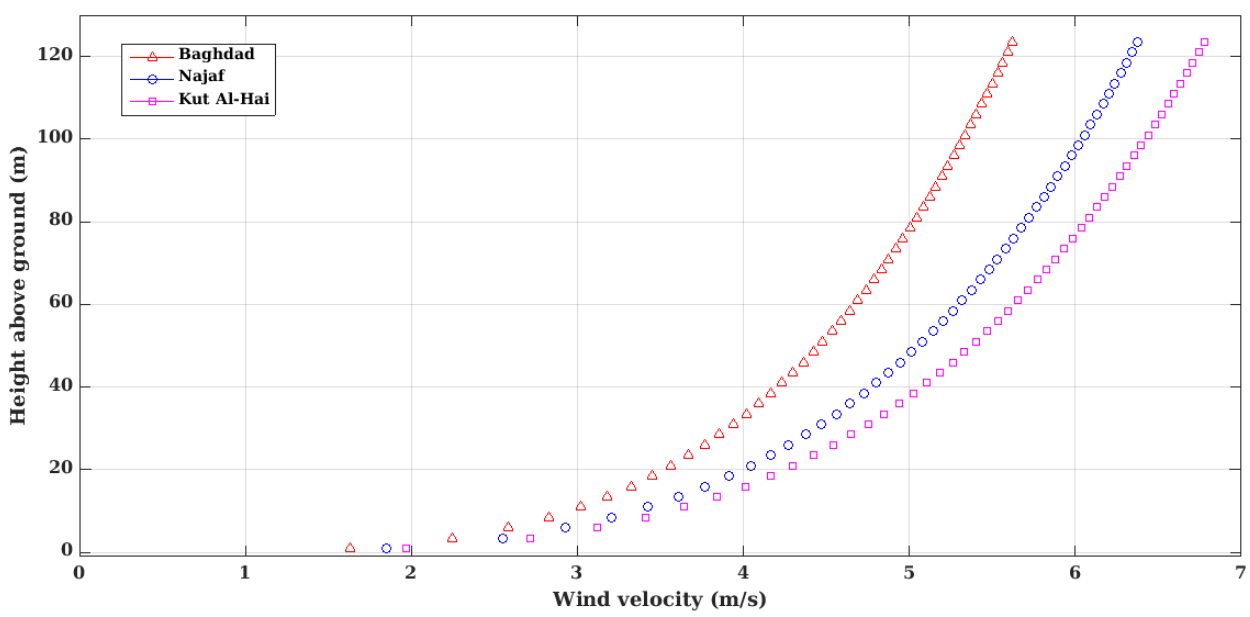

Fig 2: Variation of wind velocity with heights.

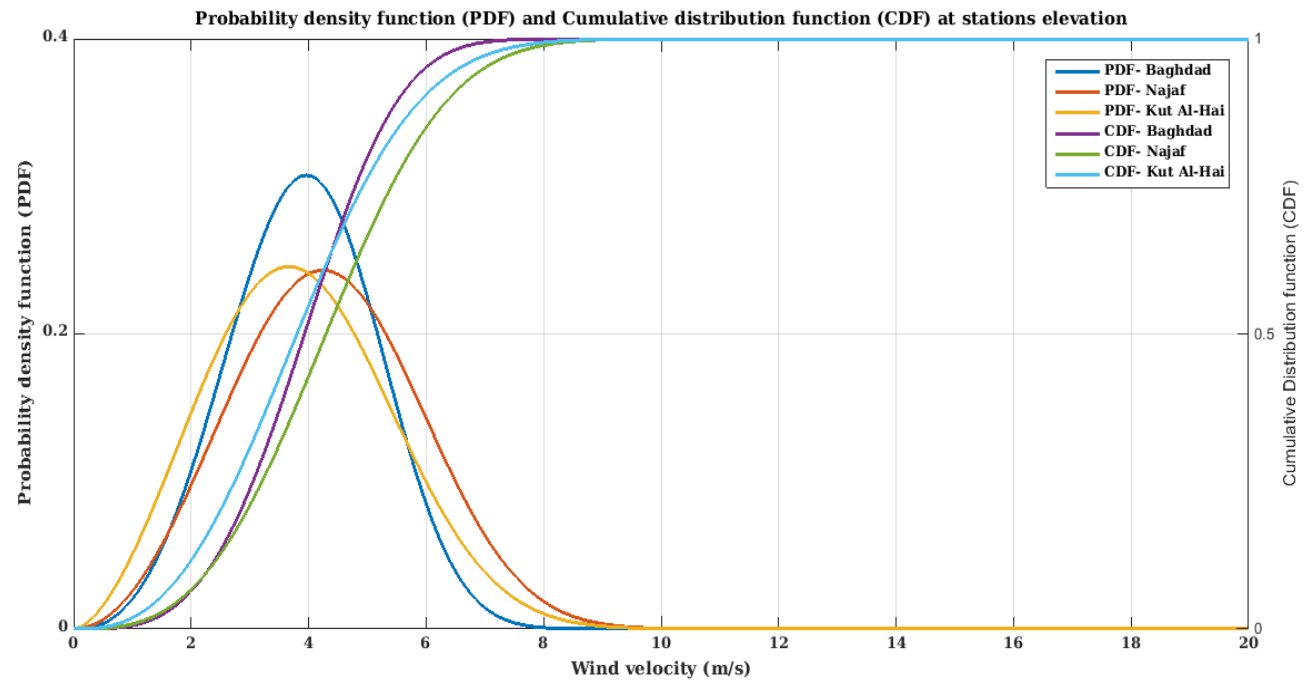

Fig 3: Weibull probability density function (PDF) and cumulative distribution function (CDF) at stations elevation.

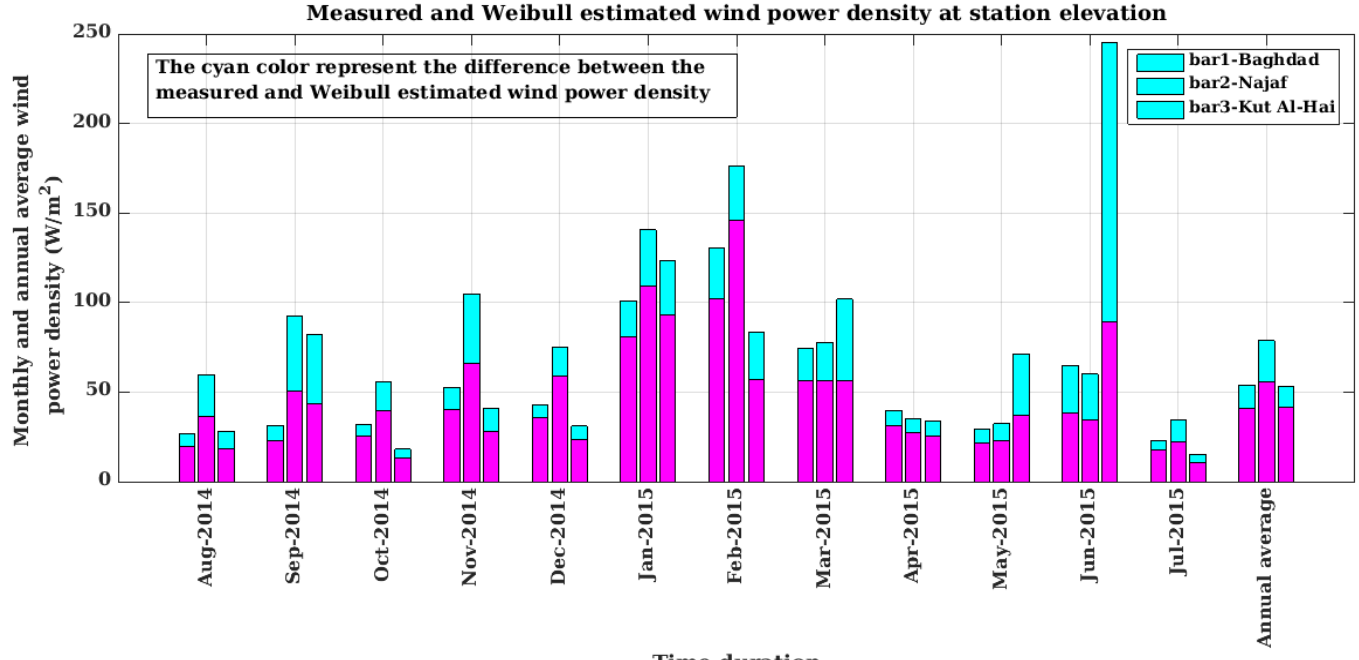

Fig 4: The monthly and annual average of wind power densities at stations elevation. 


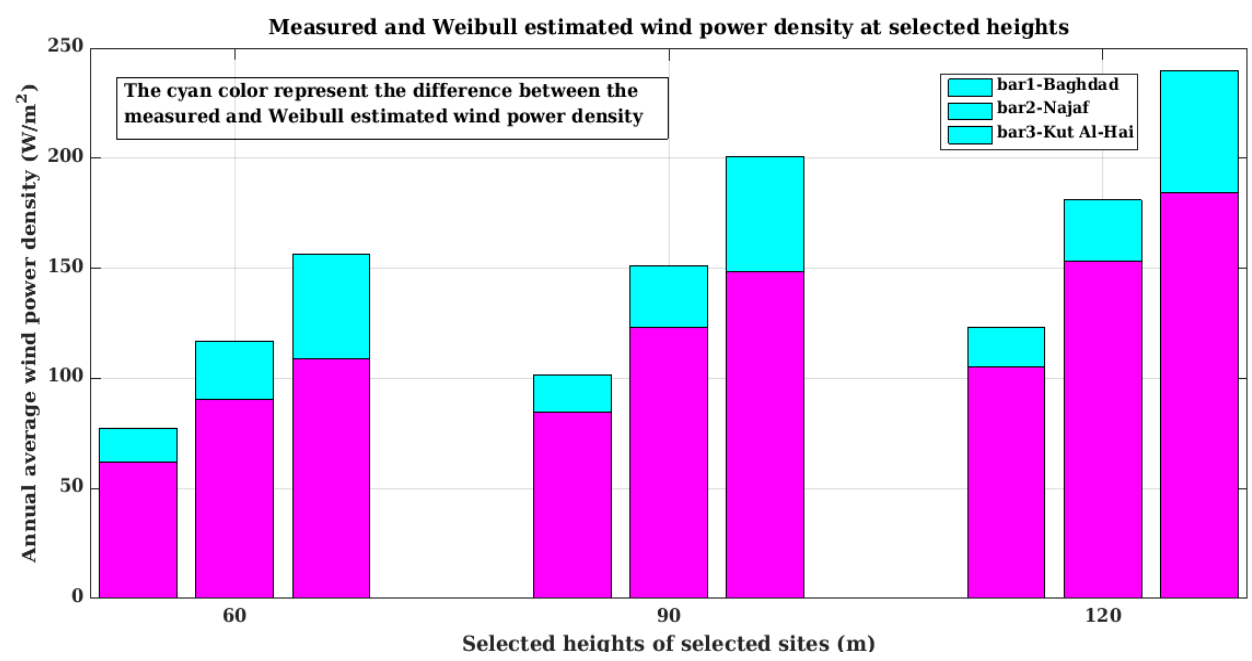

Fig 5: The annual average of wind power densities at selected heights.

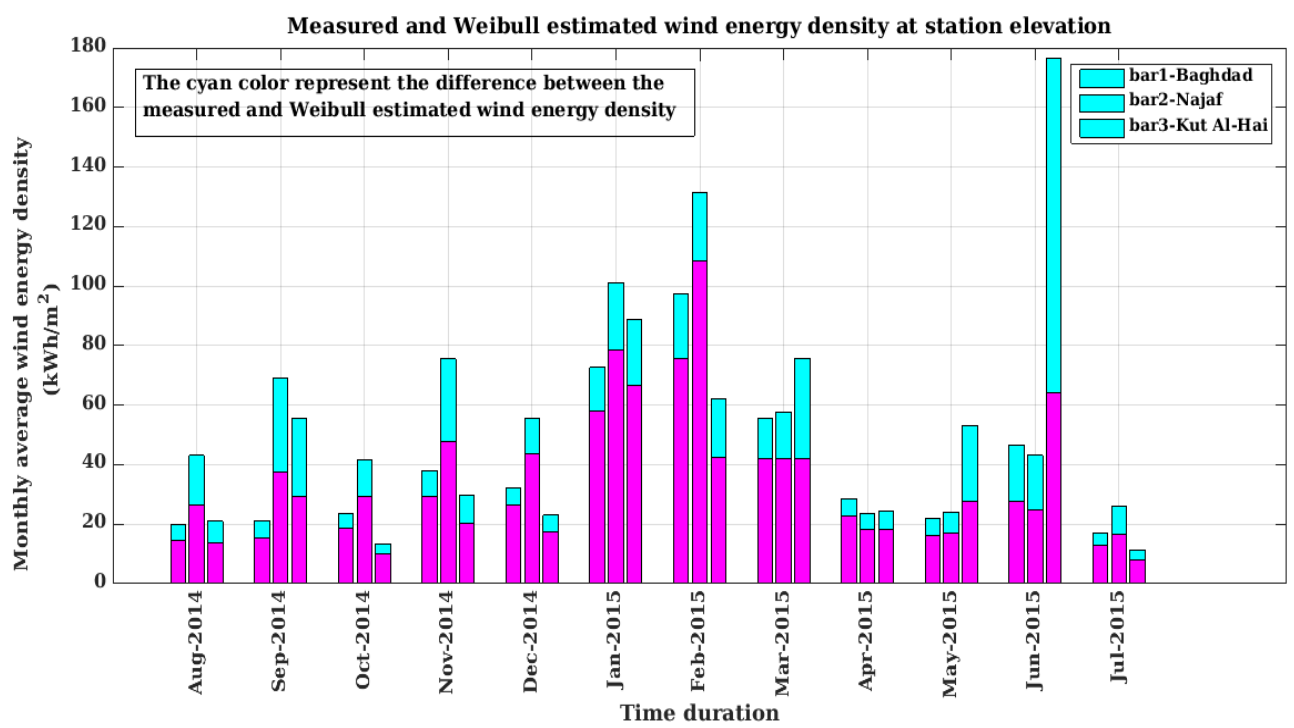

Fig 6: A monthly average of wind energy densities at stations elevation.

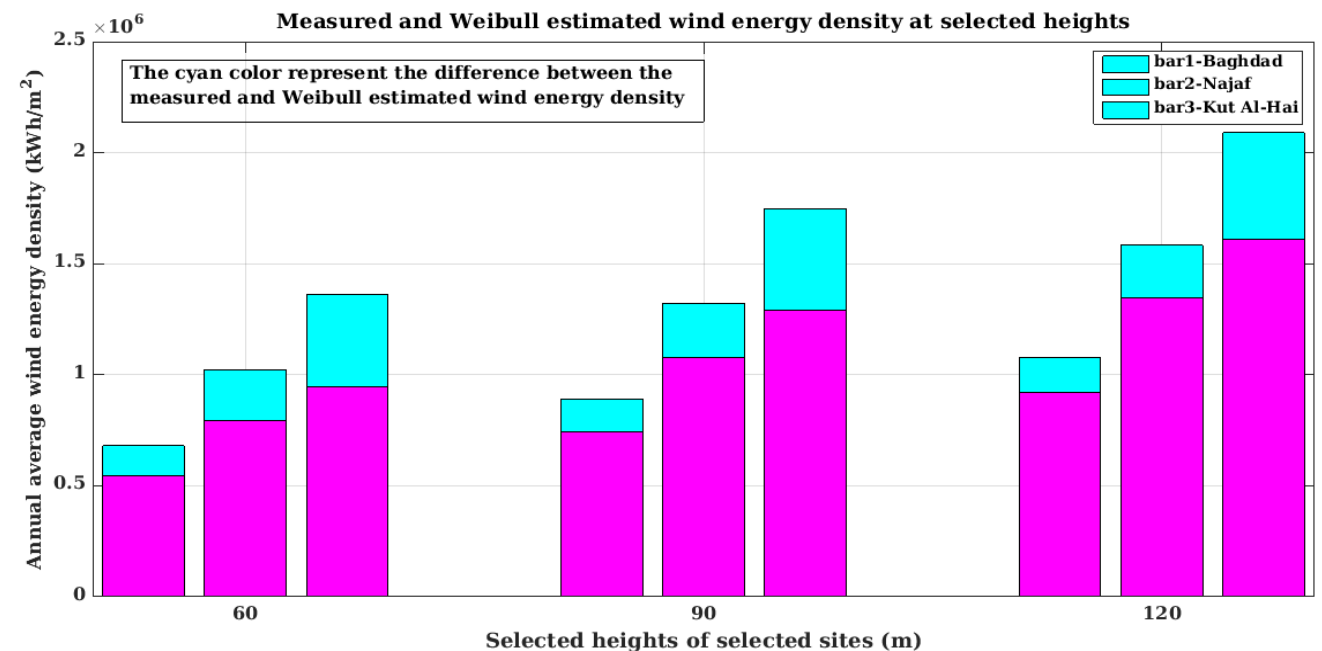

Fig 7: The annual average of wind energy densities at selected heights. 


\section{REFERENCES}

[1] Rehman, S., Ahmad, A., 2004, Assessment of wind energy potential for coastal locations of the Kingdom of Saudi Arabia, Energy 29, PP. 1105-1115, doi:10.1016/j.energy.2004.02.026.

[2] Meishen $\mathrm{Li}$, and Xianguo $\mathrm{Li}, 2005$, "Investigation of Wind Characteristics and Assessment of Wind Energy Potential for Waterloo Region, Canada", Energy Conversion and Management 46, PP. 3014-3033.

[3] Getachew Bekele, and Björn Palm, 2009, "Wind Energy Potential Assessment at Four Typical Locations in Ethiopia", Applied Energy 86 PP. 388-396.

[4] Ioannis Fyrippis, Petros J. Axaopoulos, and Gregoris Panayiotou, 2010, "Wind Energy Potential Assessment in Naxos Island, Greece", Applied Energy 87, PP. 577-586.

[5] Joseph A. Jervase, and Ali M. Al-Lawati, 2012, "Wind Energy Potential Assessment for the Sultanate of Oman", Renewable and Sustainable Energy Reviews 16, 14961507.

[6] Sunday O Oyedepo, Muyiwa S Adaramola, and Samuel S Paul, 2012, "Analysis of wind speed data and wind energy potential in three selected locations in southeast Nigeria", International Journal of Energy and Environmental Engineering, 3:7, http://www.journalijeee.com/content/3/1/7.

[7] Saeed Jahanbakhsh Asl, Majid Rezaei Banafsheh, Yagob Dinpashoh, Marziyeh Esmaeilpour, Kasra Mohammadi, Ali Mohammad Khorshiddoust, 2014, "Assessing Wind Energy potential in Kurdistan Province, Iran", Int J Energy Environ Eng, 5:100, DOI 10.1007/s40095-0140100-x.

[8] Oluseyi O Ajayi, Richard O Fagbenle, James Katende, Samson A Aasa and Joshua O Okeniyi, 2013, "Wind Profile Characteristics and Turbine Performance
Analysis in Kano, North-Western Nigeria", International Journal of Energy and Environmental Engineering, 4:27, http://www.journal-ijeee.com/content/4/1/27.

[9] Farivar Fazelpour, Nima Soltani, Marc A. Rosen, 2014, "Wind Resource Assessment and Wind Power Potential for the City of Ardabil, Iran", Int J Energy Environ Eng, DOI 10.1007/s40095-014-0139-8.

[10] Ali M. Rasham, 2016, " Analysis of Wind Speed Data and Annual Energy Potential at Three Locations in Iraq", International Journal of Computer Applications, Vol. 137, No. 11.

[11] Weather History for ORBI - August, 2014 https://www.wunderground.com/history/airport/ORBI/20 14/8/1/MonthlyHistory.html?req_city=Qaryat+Nasr+Mu bar\&req_state $=\&$ req_statename $=I r a q \&$ reqdb.zip $=00000$ $\&$ reqdb.magic $=\&$ reqdb. $w m o=$

[12] Weather History for 40670 - August, 2014 https://www.wunderground.com/history/station/40670/20 14/8/1/MonthlyHistory.html?req_city $=\&$ req_state $=\&$ req _statename $=\&$ reqdb.zip $=\&$ reqdb. magic $=\&$ reqdb. $w m o=$

[13] Weather History for 40665 - August, 2014 https://www.wunderground.com/history/station/40665/20 14/8/1/MonthlyHistory.html?req_city=\&req_state=\&req _statename $=\&$ reqdb.zip $=\&$ reqdb. magic $=\&$ reqdb.wmo $=$

[14] Sathyajith Mathew, 2006, "Wind Energy Fundamentals, Resource Analysis and Economics", (PP. 64, 68, 96, 71, 75,82 , and 83 )

[15] Mukund R. Patel, 2006, "Wind and Solar Power Systems Design, Analysis, and Operation", $2^{\text {nd }}$ edition, (PP.31).

[16] Vaughn Nelson, 2009, "Wind Energy Renewable Energy and the Environment", (PP.37).

[17] David Wood, 2011, "Small Wind Turbines Analysis, Design, and Application" (PP. 14-15). 